\title{
Pola asuh suku dayak lundayeh di kota tarakan
}

\author{
Dewi Sugiarti ${ }^{1)}$, Siti Rahmi ${ }^{*}$ ), Suriata Suriata ${ }^{3)}$ \\ 1,2,3) Universitas Borneo Tarakan \\ *) rahmisitirahmi441@gmail.com
}

\begin{abstract}
Article History:
Received: $13 / 04 / 2021$

Revised: 28/04/2021;

Accepted: 15/06/2021

Published: 28/06/2021.
\end{abstract}

How to cite:

Sugiarti, D., Rahmi, S., \& Suriata, S. (2021). Pola asuh suku dayak lundayeh di kota tarakan. Orien: Cakrawala Ilmiah Mahasiswa, 1(1), pp. 41-50. DOI:

10.30998/ocim.v1i1.4571

\section{(c) (i) This is an open} distributed under the Creative Commons 4.0 Attribution License, which permits unrestricted use, distribution, and reproduction in any medium, provided the original work is properly cited. (C) 2021, Sugiarti, D., Rahmi, S., \& Suriata, S..

\begin{abstract}
Abstrak: Setiap keluarga memiliki pola asuh yang berbeda. Pola asuh adalah suatu cara mendidik anak untuk memberikan dorongan bagi anak dengan mengubah tingkah laku, pengetahuan, dan nilai-nilai yang dianggap paling tepat dalam bermasyarakat. Tujuan dari penelitian ini adalah untuk mengetahui bagaimana pola asuh suku Dayak Lundayeh di Kota Tarakan. Data dikumpulkan dengan wawancara, observasi dan dokumentasi. Data dianalisis dengan model Miles and Huberman. Hasil penelitiannya adalah pola asuh yang diterapkan oleh orang tua suku Dayak Lundayeh kepada anak-anaknya adalah pola asuh demokratis dan orang tua suku Dayak Lundayeh masih memegang adat istiadat seperti bak tang bak kukut (basah mulut basah lutut), maksudnya adalah bila menginginkan sesuatu maka berusaha untuk menggapainya, dan mengajarkan untuk tidak mudah putus asa kepada anak-anaknya. Berdasarkan fenomena tersebut diharapkan penelitian ini dapat dijadikan sebagai salah satu referensi bagi peneliti selanjutnya yang ingin meneliti tentang objek penelitian yang sama.
\end{abstract}

Kata Kunci: pola asuh, suku dayak, lundayeh

Abstract: Each family has different parenting pattern. Parenting is a way of educating children in providing encouragement for children to change their behavior, knowledge, and values so that they become independent, grow healthy, friendly and have confidence, and curiosity. The purpose of this study was to find out parenting patterns of the Dayak Lundayeh in Tarakan city. Data were collected though interviews, observation and documentation. Data were analyzed using the Miles and Huberman model. The results showed that the parenting pattern applied by dayak lundayeh parents was a democratic parenting. The parents of still held customs such as bak tang bak kukut (wet mouth wet knees), which meant if you want something, you have to try to get it, and teach your children not to give up easly. It is hoped that this research can be used as a reference for further researchers who want to examine the same research object.

Keywords: parenting, dayak tribe, lundayeh

\section{Pendahuluan}

Dalam kehidupan, tempat pertama untuk belajar dan memperoleh pelajaran adalah keluarga. Keluarga merupakan sekumpulan orang-orang yang terdiri dari ayah, ibu dan anak. Dalam pengertian pedagogis keluarga adalah satu persekutuan hidup yang dijalani dengan kasih sayang antara pasangan dua jenis manusia yang dikukuhkan dalam pernikahan, yang bermaksud untuk saling menyempurnakan diri. Dalam usaha saling melengkapi dan menyempurnakan diri itu terkandung perselisihan peran dan fungsi sebagai orang tua (Shochib, 2014). 
Keutuhan dalam keluarga sangat dibutuhkan anak, karena perannya yang penting yang diberikan oleh ibu dan ayah. Keluarga yang utuh memberikan kepercayaan terhadap anak dan membantu anak dalam perkembangan baik dalam aspek fisik, kecerdasan emosional, maupun sosial. Menurut Ekawati (2016), perkembangan emosi pada anak sangatlah penting, hal ini mempengaruhi kehidupannya di masa yang akan datang. Emosi merupakan ungkapan perasaan seseorang terhadap apa yang sedang mereka alami. Pada usia anak-anak biasanya perkembangan cukup pesat sehingga perlu adanya stimulus yang tepat agar perkembangan emosi pada anak-anak dapat berkembang secara optimal dan sesuai dengan tahap perkembangan anak.

Menurut Dinar (2008) anak adalah bayi dilahirkan seperti tabularasa atau kertas kosong. Pikiran anak merupakan hasil dari pengalaman dan proses belajar yang diperoleh melalui lingkungan. Pengalaman dan proses belajar diperoleh melalui indra membentuk manusia menjadi individu yang baik, dan anak sejak dilahirkan, ia sudah dibekali oleh rasa keadilan dan moralitas, perasaan dan pemikiran.

Dalam setiap keluarga pastinya memiliki pola asuh yang berbeda-beda dalam mengasuh anak. Pola asuh terdiri dari dua kata yaitu pola dan asuh. Menurut Kamus Besar Bahasa Indonesia, pola berarti corak, model, sistem, cara kerja, bentuk (struktur) yang tetap. Ketika pola diberi arti bentuk/struktur yang tetap,maka hal itu semakna dengan istilah kebiasaan. Asuh yang berarti mengasuh, satu bentuk kata kerja yang bermakna menjaga (merawat dan mendidik) anak kecil, membimbing (membantu, melatih, dan sebagainya) supaya dapat berdiri sendiri, memimpin (mengepalai, menyelenggarakan) suatu badan kelembagaan. Ketika mendapat awalan dan akhiran, kata asuh memiliki makna yang berbeda. Pengasuhan berarti orang tua yang mengasuh; wali (orang tua dan sebagainya). Pengasuhan berarti proses, perbuatan, cara pengasuhan.

Menurut Susanto (2015), pola asuh merupakan sikap orang tua dalam berinteraksi dengan anak-anaknya. Menurut pandangan para ahli psikologi dan sosiologi berbeda. Pola asuh menurut Tridhonanto (2014) sebagai gambaran yang dipakai orang tua dalam mengasuh (merawat, menjaga, mendidik) anak. Sedangkan menurut Gunarsa (2002) pola asuh adalah cara orang tua bertindak sebagai orang tua terhadap anak-anaknya dimana mereka melakukan serangkaian usaha aktif.

Menurut Stewart \& Koch (Susanto, 2015) pola asuh dibagi menjadi tiga tipe atau jenis yaitu; (1) Pola asuh demokratis, apabila anak diasuh dengan pola asuh demokratis maka tumbuh kembang anak akan lebih baik. Jika pola asuh demokratis yang diterapkan orang tua kepada anaknya maka kelak anak akan cenderung mempunyai rasa percaya diri yang tinggi, tidak tergantung kepada orang tuanya, berani mengungkapkan pendapat. (2) Pola asuh otoriter, dimana anak akan cenderung menjadi takut untuk melakukan sesuatu karena selalu diawasi dan dikekang oleh orang tuanya dan akan mengakibatkan anak menjadi penakut, suka berbohong, tidak percaya diri, bergantung kepada orang tua, pendiam, pemurung. (3) Pola asuh permisif. Dimana orang tua cenderung tidak peduli, acuh tak acuh terhadap anak, sehingga anak cendrung menjadi pemarah, emosi tidak terkontrol, pemberontak agar bisa mendapatkan perhatian dari orang tua.

Menurut Bahri (2014) pola asuh orangtua dalam keluarga tampil dalam berbagai tipe yaitu ada lima belas macam tipe pola asuh orang tua dalam keluarga sebagai berikut:

a. Gaya otoriter

Tipe pola asuh otoriter adalah tipe pola asuh yang memaksa kehendak. Dengan tipe orang tua ini cenderung sebagai pengendali atau pengawas, selalu memaksakan kehendak kepada anak, tidak terbuka terhadap anak, sangat sulit menerima saran dan cenderung 
memaksakan kehendak dalam perbedaan, terlalu percaya diri sendiri sehingga menutup katup musyawarah. Dalam upaya mempengaruhi anak sering menggunakan pendekatan yang mengandung unsur paksaan dan ancaman. Kata-kata yang diucapkan oleh orang tua adalah hukuman atau peraturan dan tidak dapat diubah, memonopoli tindak komunikasi dan seringkali meniadakan umpan balik dari anak. Hubungan antarpribadi antara orang tua dan anak cenderung renggang dan berpotensi berlawanan. Pola asuh ini sangat cocok untuk anak PAUD dan TK dan masih bisa digunakan untuk anak SD dalam kasus-kasus tertentu.

b. Gaya demokratis

Tipe pola asuh demokratis adalah tipe pola asuh yang terbaik dari semua tipe pola asuh yang ada. Hal ini di sebabkan tipe pola asuh orang tua yang tidak banyak menggunakan kontrol terhadap anak. Pola ini dapat digunakan untuk anak SD, SMP, SMA, dan perguruan tinggi. Beberapa ciri dari tipe pola asuh yang demokratis adalah sebagai berikut;

1) Dalam proses pendidikan terhadap anak selalu bertitik tolak dari pendapat bahwa manusia itu adalah makhluk yang termulia di dunia.

2) Orang tua selalu berusaha menyelaraskan kepentingan dan tujuan pribadi dengan kepentingan anak.

3) Orang tua senang menerima saran, pendapat,dan bahkan kritik dari anak.

4) Menolerir ketika anak membuat kesalahan dan memberikan pendidikan kepada anak agar jangan berbuat kesalahan dengan tidak mengurangi daya kreativitas, inisiatif, dan prakarsa dari anak.

5) Lebih menitikberatkan kerja sama dalam mencapai tujuan.

6) Orang tua selalu berusaha untuk menjadikan anak lebih sukses darinya.

Tipe pola asuh demokratis mengharapkan anak untuk berbagi tanggung jawab dan mampu mengembangkan potensi kepemimpinan yang dimilikinya, memiliki kepedulian terhadap hubungan antarpribadi dalam keluarga. Meskipun tampak kurang terorganisasi dengan baik, namun gaya ini dapat berjalan dalam suasana yang rileks dan memiliki kecenderungan untuk menghasilkan produktivitas dan kreativitas, karna tipe pola asuh demokratis ini mampu memaksimalkan kemampuan yang dimiliki anak.

c. Gaya laissez-faire

Tipe pola asuh laissez-faire tidak berdasarkan aturan-aturan. Kebebasan memilih terbuka bagi anak dengan sedikit campur tangan orang tua agar kebebasan yang diberikan terkendali. Bila tidak ada kendali dari orang tua, maka perilaku anak tidak terkendali, tidak terorganisasi, tidak produktif dan apatis, sebab anak merasa tidak memiliki maksud dan tujuan yang hendak dicapai. Orang tua yang menggunakan gaya ini menginginkan seluruh anaknya berpartisipasi tanpa memaksakan atau menuntut kewenangan yang dimilikinya. Tindak komunikasi dari orang tua cenderung berlaku sebagai seorang penghubung yang menghubungkan kontribusi atau sumbangan pemikiran dari anggota keluarga. Pola asuh ini bisa digunakan untuk anak dalam semua usia

d. Gaya fathernalistik

Fathernalistik (fathernal=kebapakan) adalah pola asuh kebapakan, dimana orang tua bertindak sebagai ayah terhadap anak dalam perwujudan mendidik, mengasuh, mengajar, membimbing, dan menasehati. Orang tua menggunakan pengaruh sifat kebapakannya untuk menggerakkan anak mencapai tujuan yang diinginkan meskipun terkadang pendekatan yang dilakukan bersifat sentimental. Di balik kebaikannya, kelemahannya adalah tidak memberikan kesempatan kepada anak untuk tumbuh menjadi dewasa dan bertanggung jawab. Itulah sebabnya, tipe pola asuh ini diberikan ciri-ciri berdasarkan sifat-sifat orang tua sebagai pemimpin. Di antara sifat-sifat umum tipe pola asuh kebapakan adalah orang tua 
menganggap anak sebagai manusia yang tidak dewasa, terlalu melindungi anak, tidak memberikan kesempatan kepada anak untuk mengambil keputusan dan untuk mengembangkan inisatif dan kreasi, orang tua sering menganggap dirinya serba tahu. Pola asuh ini cocok digunakan untuk anak PAUD dan TK dalam kasus-kasus tertentu dan sangat pas digunakan untuk anak usisa 0-2 tahun.

e. Gaya karismatik

Tipe pola asuh karismatik adalah pola asuh orang tua yang memiliki kewibawaan yang kuat. Kewibawaan itu hadir bukan karena kekuasaan atau ketakutan, tetapi karena adanya relasi kejiwaan antara orangvtua dan anak. Adanya kekuatan internal luar biasa yang diberkahi kekuatan gaib oleh Tuhan dalam diri orang tua sehingga dalam waktu singkat dapat menggerakan anak tanpa bertahan. Pola asuh ini baik selama orang tua berpegang teguh kepada nilai-nilai moral dan akhlak yang tinggi dan hukum-hukum yang berlaku. Pola asuh ini dapat berdaya guna terhadap anak usia SD, SMP, SMA, dan perguruan tinggi.

f. Gaya melebur diri (affiliate)

Pola asuh dengan tipe melebur diri (affiliate) adalah tipe kepemimpinan orang tua yang mengedepankan keharmonisan hubungan dan membangun kerja sama dengan anak dengan cara menggabungkan diri. Ini tipe yang berusaha membangun ikatan yang kuat antara orang tua dan anak, berupaya menciptakan perasaan cinta, membangun kepercayaan dan kesetiaan antara orang tua dan anak. keakraban antara orang tua dan anak terjalin sangat harmonis. Pola asuh ini bisa dipakai untuk anak PAUD dan TK.

g. Gaya pelopor

Tipe pola asuh orang tua yang satu ini biasanya selalu berada di depan (pelopor) untuk memberikan contoh atau suri teladan dalam kebaikan bagi anak dalam keluarga. Orang tua benar-benar tokoh yang patut diteladani karena sebelum menyuruh atau memerintah anak, ia harus lebih dulu berbuat. Dengan kata lain, orang tua lebih banyak sebagai pelopor di segala bidang demi kepentingan pendidikan anak. Pola asuh ini dapat digunakan untuk anak di semua usia.

h. Gaya manipulasi

Tipe pola asuh ini selalu menggunakan tipuan, rayuan, memutarbalikkan kenyataan. Agar apa yang dikehendaki tercapai orang tua menipu dan merayu anak agar melakukan yang dikehendakinya. Orang tua selalu memutarbalikan fakta atau memanipulasi keadaan sebenarnya. Pola asuh orang tua yang bergaya manipulasi biasanya berhasil mencapai tujuan karena anak yang diperlakukan tidak tahu maksud orang tuanya. Pola asuh ini sampai batasbatas tertentu dan sangat hati-hati masih bisa digunakan untuk anak PAUD dan TK karena mereka cenderung belum bisa diberi pengertian dan sangat tidak cocok untuk anak SD, SMP dan SMA. Jangan kesan ada hantu, jangan menduduki bantal nanti berbisul, jangan duduk di pintu nanti lambat kawin adalah beberapa contoh dari sekian banyak contoh dalam tradisi di masyarakat.

i. Gaya transaksi

Pola asuh orang tua tipe ini selalu melakukan perjanjian (transaksi), di mana orang tua dan anak membuat kesepakatan dari setiap tindakan yang diperbuat. Orang tua menghendaki anaknya mematuhi dalam wujud melaksanakan perjanjian yang telah disepakati. Ada sanksi tertentu yang dikenakan kepada anak jika suatu waktu anak melanggar perjanjian tersebut. pola asuh ini cocok digunakan untuk anak SD dan SMP.

j. Gaya biar lambat asal selamat

Pola asuh orang tua tipe ini melakukan segala sesuatunya sangat berhati-hati. Orang tua berprinsip biar lambat asal selamat, biar pelan pasti melompat jauh ke depan. Orang tua tidak 
mau terburu-buru, tetapi selalu memperhitungkan secara mendalam sebelum bertindak. Dalam berbicara orang tua menggunakan bahasa lemah lembut, sopan dalam kata-kata, santun dalam untaian kalimat. Pola asuh ini cocok digunakan pada anak PAUD, TK, SD, dan SMP.

k. Gaya ahli peran

Pola asuh gaya ahli peran ini adalah tipe kepemimpinan orang tua dengan cara mendelegasikan wewenang dan tanggung jawab kepada anak. Pola asuh ini dipakai orang tua untuk memberikan kesempatan kepada anak untuk mengemban tugas dan peran tertentu. Orang tua hanya memfasilitasi dan membantu ketika solusi atas masalah tidak ditemukan oleh anak. Meskipun tidak diberikan arahan secara detail apa yang harus anak lakukan, tetapi tanggung jawab dan proses pengambilan keputusan sebagian besar diserahkan kepada anak. Pendelegasian wewenang dan tanggung jawab kepada anak akan berjalan baik apabila anak telah paham dan efisien dalam pekerjaan, sehingga kita dapat melepas mereka menjalankan tugas atau pekerjaan itu atas kemampuan dan inisiatifnya sendiri. Pola asuh ini cocok digunakan untuk anak SMP, SMA, dan Perguruan tinggi.

1. Gaya pamrih

Tipe pola asuh ini disebut pamrih (gentong ngumes = Sunda), karena setiap hasil kerja yang dilakukan adalah nilai material. Bila orang tua ingin menggerakkan anak untuk melakukan sesuatu, maka ada imbalan jasanya dalam bentuk material. Jadi, karena ingin mendapatkan imbalan jasa itulah anak terdorong melakukan sesuatu yang diperintahkan oleh orang tua. Pola asuh ini cocok digunakan pada anak PAUD, TK, SD, SMP, tetapi dalam hal tertentu.

m. Gaya tanpa pamrih

Tipe pola asuh ini disebut tanpa pamrih, karena asuhan yang dilaksanakan orang tua kepada anak mengajarkan keikhlasan dalam perilaku dan perbuatan. Tidak pamrih berarti tidak mengharapkan sesuatu pun kecuali mengharapkan rida Tuhan. Pola asuh ini bisa digunakan untuk anak dalam semua tingkatan usia.

n. Gaya konsultan

Tipe pola asuh ini menyediakan diri, sebagai tempat keluh kesah anak, membuka diri menjadi pendengar yang baik bagi anak. Orang tua siap sedia bersama anak untuk mendengarkan cerita, informasi, kabar, dan keluhan tentang berbagai hal yang telah dibawa anak dari pengalaman hidupnya. Komunikasi dua arah terbuka antara orang tua dan anak, dimana keduanya dengan posisi dan peran yang berbeda. Orang tua berperan sebagai konsultan dan anak berperan sebagai orang yang menyampaikan pesan. Keduanya terlibat dalam komunikasi yang dialogis tentang segala sesuatu. Pola asuh ini dapat digunakan untuk anak dalam berbagai tingkatan usia

o. Gaya militeristik

Pola asuh ini adalah tipe kepemimpinan orang tua yang suka memerintah. Tanpa dialog, anak harus mematuhi perintahnya. Tidak boleh dibantah, harus tunduk dan patuh pada perintah dan larangan. Dalam keadaan tertentu, ada ancaman. Dalam keadaan berbahaya, tipe ini sangat tepat digunakan untuk menggerakan anak karena harus secepatmya dan tepat dalam mengambil keputusan demi keselamatan anak. Dalam hal tertentu, pola asuh ini dengan kebijakan orang tua dan sangat hati-hati bisa digunakan untuk anak PAUD, TK, dan SD.

Berdasarkan uraian di atas salah satu faktor penting yang berhubungan dengan keluarga adalah pola asuh orang tua terhadap anaknya. Seperti halnya dalam keluarga suku Dayak Lundayeh memiliki cara tersendiri dalam mengasuh anak, yang membuat seorang anak memiliki kepribadian dan karakter tersendiri. Dalam pelaksanaan pendidikan, keluarga bukan hanya 
berperan sebagai pelaksana yang bersifat rutin dan alamiah, melainkan berperan sebagai pengelola yang bertanggung jawab dalam meletakkan landasan dan memberikan bobot dan arah serta pola-pola kehidupan anak.

Beberapa ahli psikologi pendidikan menyampaikan bahwa untuk meningkatkan mutu pendidikan, memulainya harus dari pendidikan anak usia dini. Bimbingan dan Konseling juga diajarkan di dalam Konseling Lintas Budaya dimana Indonesia memliki berbagai macam suku dan budaya. Di setiap pulau yang ada di Indonesia yang pastinya berbeda satu dengan yang lainnya. Di setiap suku dan budaya yang ada di Indonesia memiliki cara sendiri dalam mengasuh anak.

Berdasarkan observasi yang dilakukan pada tanggal 15 April 2020 peneliti mendapatkan data di mana banyak anak-anak dari suku Dayak Lundayeh yang sukses dan melajutkan pendidikan ke jenjang yang lebih tinggi, juga cenderung memiliki tekad yang kuat, mudah menyesuaikan diri dengan lingkungan yang baru, ramah terhadap orang di sekitar, dan orang tua suku Dayak Lundayeh mendoktrin anak-anaknya dalam tiga hal: 1) tidak berbohong, 2) tidak mencuri, dan 3) mengejar ilmu. Orang tua juga mengajarkan anak untuk tidak mudah putus asa dalam menjalani kehidupan.

Dayak Lundayeh merupakan masyarakat asli pulau Kalimantan yang bertempat tinggal di Kabupaten Nunukan, Kalimantan Utara. Saat ini masyarakat suku Dayak Lundayeh sudah tersebar di berbagai daerah, diantaranya Nunukan, Malinau, Tanjung Selor, Tarakan, Samarinda dan lain-lain. Masyarakat suku Dayak Lundayeh berasal dari masyarakat yang sangat sederhana dimana mereka mengantungkan hidup mereka dari hasil bumi pertanian. Pada tahun 1929 terjadi perubahan besar yang dirasakan masyarakat Dayak Lundayeh karena pada tahun itu adalah awal dimana masyarakat mulai mengenal adanya agama yaitu agama Kristen. Masyarakat Dayak Lundayeh termasuk masyarakat yang terbuka dan dapat menerima perubahan, yang menyebabkan agama Kristen dapat tersebar dengan sangat cepat dalam kehidupan masyarakat Lundayeh.

Saat ini Masyarakat suku Dayak Lundayeh masih memegang adat istiadat seperti tradisi lisan yang diturunkan oleh nenek moyang dari generasi ke generasi. Masyarakat suku Dayak Lundayeh hidup dengan kentalnya budaya adat seperti bertani, beragam pola budaya yang hidup dan berkembang dengan subur. Di Kota Tarakan banyak ditempati oleh masyarakat suku Dayak Lundayeh. Mereka hidup rukun dengan masyarakat lainnya. Tradisi tersebut menjadi sebuah pedoman dalam penerapan pola asuh masyarakat terutama orang tua terhadap anaknya.

Menurut Yansen TP \& Ricky YG (2018) Dr. Yansen TP adalah anak yang dibesarkan dalam perjalanan pengabdian dari orang tuanya sebagai seorang guru. sehingga YTP memperoleh cendekiawan, intelektual, dan juga menjadi seorang pemimpin politik dan organisasi masyarakat khususnya Lundayeh.

Gaya dari didikan orang tua YTP kepadanya memberikan pemahaman untuk mengembangkan konsep hidup yang baik dan benar. Menurut Yansen (2018) jika seorang mau menjadi sukses dan berprestasi, maka dia harus memiliki beberapa sifat perilaku: 1) selalu bisa tahu tentang banyak hal, dan memahami semua sisi dengan baik, 2) bisa melakukan dan mengerjakan apa yang telah diketahui dan dipahami dengan baik, dan 3) harus bisa mewujudkan suatu kenyataan sebagaimana yang didambakan.

Menurut (YB) cara mendidik anak adalah dengan seringkali memotivasi dan memberi nasihat kepada anaknya dalam melakukan segala aktivitas maupun mengambil atau membuat keputusan. Jika ada salah satu anak yang sukses misalnya sudah mendapatkan pekerjaan seperti guru, itu menjadi suatu kebanggaan tersendiri bagi orang tua. Sedangkan menurut (DJ) orang tua yang mendidik dia mengajarkan untuk tidak mudah putus asa dalam menjalani kehidupan 
ini. Selanjutnya mengajarkan untuk menjadi anak yang mandiri dan tidak mudah putus asa. Selama orang tua mendidiknya dia tidak pernah dipukul secara fisik, bila dia melakukan kesalahan orang tua akan mendengarkan alasan anaknya kenapa dia melakukan kesalahan dan memberikan motivasi kembali kepada anak agar anak tidak mengulangi kembali kesalahannya

Berdasarkan latar belakang tersebut penulis penasaran untuk menggali lebih dalam mengenai pola asuh yang diterapkan oleh orang tua suku Dayak Lundayeh terhadap anaknya melalui penelitian berjudul Pola Asuh Suku Dayak Lundayeh Di Kota Tarakan.

\section{Metode}

Penelitian ini menggunakan jenis penelitian kualitatif. Menurut Prastowo (2016) jenis penelitian kualitatif adalah prosedur penelitian yang sistematis yang digunakan untuk mengkaji atau meneliti suatu objek pada latar alamiah tanpa adanya manipulasi di dalamnya dan tanpa adanya pengujian hipotesis, dengan metode-metode yang alamiah ketika hasil penelitian yang diharapkan bukanlah generalisasi berdasarkan ukuran-ukuran kuantitas, namun makna (segi kualitas) dari fenomena yang diamati. Desain dari penelitian ini adalah deskriptif kualitatif yang dimana data yang didapatkan akan dideskripsikan atau digambarkan (Sugiyono, 2015). Subjek penelitian merupakan sesuatu yang kedudukannya sangat sentral karena pada subjek penelitian itulah data tentang variabel yang diteliti berada dan diamati oleh peneliti (Arikunto, 2006).

Peneliti menentukan subjek penelitian menggunakan purposive sampling yaitu teknik pengambilan sampel sumber data dengan pertimbangan tertentu (Sugiyono, 2014). Alasan menggunakan teknik purposive sampling adalah karena tidak semua sampel memiliki kriteria yang sesuai dengan fenomena yang diteliti. Oleh karena itu, peneliti memilih teknik purposive sampling yang menetapkan pertimbangan-pertimbangan atau kriteria-kriteria tertentu yang harus dipenuhi oleh sampel-sampel yang digunakan dalam penelitian ini. Adapun kriterianya yaitu:1) memiliki anak yang sudah berprofesi dan 2) memiliki anak yang sedang menuntut pendidikan di perguruan tinggi. Data dikumpulkan melalui teknik wawancara, obervasi, dan catatan dokumentasi. Data dianalisis dengan menggunakan model Miles dan Huberman yang terdiri dari reduksi data, tampilan data, dan verifikasi. Reduksi data merupakan kegiatan merangkum, memilah hal yang pokok, memfokuskan pada hal-hal yang penting, dicari tema dan pola. melalui penyajian data, data diorganisasikan, disusun dalam pola hubungan, sehingga akan semakin mudah untuk dipahami dan merencanakan kerja selanjutnya. Penyajian data dapat berupa uraian singkat, bagan, hubungan antarkategori, flowchart, dan sejenisnya. Penyajian data tersebut menjadi lebih terorganisir dan lebih mudah untuk dipahami. Kesimpulan dalam penelitian kualitatif menjawab rumusan masalah yang telah disampaikan. Data diabsahkan melalui teknik triangulasi.

\section{Hasil dan Diskusi}

Berdasarkan hasil penelitian tentang pola asuh suku Dayak Lundayeh di Kota Tarakan, dapat diuraikan bahwa adanya peranan penting orang tua dalam mengasuh anaknya. Setiap orang tua memiliki metode pola asuh yang berbeda bagi anaknya. Ada yang mendidik dengan disiplin, keras, saling mengasihi sesama, ada juga yang sangat memanjakan. Penelitian yang menunjukan bahwa kasih sayang yang diberikan sejak dini kepada bayi penting dalam perkembangan kepribadian, kecerdasan anak, begitu pula dengan pola asuh yang diterapkan 
orang tua suku Dayak Lundayeh, meskipun waktu yang diluangkan sedikit kepada anak mereka tetap mengusahakan yang terbaik.

Dalam mengasuh anak, sesungguhnya memiliki aturan-aturan yang ditaati dalam keluarga, mengajarkan untuk bersikap terbuka, orang tua mendengarkan pendapat anak, memberikan kebebasan yang sesuai dengan kemampuan yang dimiliki, memberikan waktu untuk bersama dan berkumpul dengan anak, dan memberikan dukungan pada kegiatan yang dilakukan.

Menurut Bahri (2014) pola asuh demokratis memiliki ciri-ciri sebagai berikut: 1) dalam proses pendidikan terhadap anak selalu bertitik tolak dari pendapat bahwa manusia itu adalah mahluk yang mulia di dunia, 2) orang tua selalu berusaha menyelaraskan kepentingan dan tujuan pribadi dengan kepentingan anak, 3) orang tua senang menerima saran, pendapat, dan bahkan kritik dari anak, 4) menolerir ketika anak berbuat salah dan memberikan pendidikan kepada anak agar anak tidak berbuat kesalahan dengan tidak menguragi daya kreativitas, inisiatif, dan prakarsa dari anak, 5) lebih menitik beratkan kerja sama dalam mencapai tujuan, dan 6) Orang tua selalu berusaha untuk menjadikan anak lebih sukses darinya.

Menurut Tridhonanto (2014) pola asuh demokratis memiliki ciri-ciri sebagai berikut; anak diberikan kesempatan untuk mandiri, anak diakui sebagai pribadi oleh orang tua dan turut dilibatkan dalam pengambilan keputusan, menetapkan peraturan kehidupan anak, memprioritaskan kepentingan anak, akan tetapi tidak ragu-ragu dalam mengendalikan mereka. Bersikap realistis terhadap kemampuan anak, memberikan kebebasan kepada anak untuk memilih dan melakukan suatu tindakan, pendekatan kepada anak bersifat hangat. Menurut Bety (2012) pola asuh authoritative atau demokratis adalah orang tua sangat memperhatikan kebutuhan anak, dan mencukupinya dengan pertimbangan faktor kepentingan dan kebutuhan. Syarat pola asuh ini adalah: 1) utamakan kehangatan atau kasih sayang yang mendalam. Wujud kehangatan adalah pelukan erat, bermain bersama, bercerita atau bertukar pendapat, 2) saat memberlakukan batasan, orang tua harus tegas dan konsisten sehingga anak akhirnya belajar bahwa orang tuanya tidak main-main dengan aturan yang sudah ditetapkan, 3) orang tua tidak boleh memaksakan kehendaknya, dan 4) orang tua jangan sampai mengabaikan anak.

Berdasarkan wawancara dan observasi beberapa orang tua suku Dayak Lundayeh pola asuh yang diterapkan adalah pola asuh demokratis dimana dalam keluarganya masih memegang teguh ajaran nenek moyang yang berbunyi bak tang, bak kukut artinya basah mulut, basah lutut, maksudnya adalah mengajarkan anak untuk memiliki sikap pantang menyerah dan tidak mudah putus asa dalam menghadapi rintangan, memiliki keinginan tinggi, tekad kuat dalam menggapai cita-citanya. Di dalam keluarga juga memiliki aturan yang ditaati, memberikan nasihat, mengajarkan sikap terbuka, membantu menyelesaikan masalah, bersikap tegas kepada anak bila melakukan kesalahan, meluangkan waktu, mengajarkan untuk berkata jujur, dan tidak mencuri.

Contohnya seperti bila anak sedang mengalami kesulitan dalam menyelesaikan masalah atau hal apapun, orang tua dalam suku Dayak Lundayeh akan membantu menyelesaikan dengan tenang, bersahabat, profesional, dan memberikan kesempatan untuk memperbaiki kesalahan. Bukan hanya dalam menyelesaikan masalah, orang tua juga selalu mendukung setiap kegiatan yang dilakukan selama tidak melangkar aturan, norma, dan adat istiadat yang berlaku.

\section{Simpulan}

Kesimpulan dari hasil penelitian yang dilakukan oleh peneliti di Tarakan bahwa pola asuh orang tua suku Dayak Lundayeh yang diberikan kepada anak-anaknya adalah pola asuh 
demokratis. Orang tua masih memegang ajaran nenek moyang yaitu bak tang, bak kukut artinya basah mulut basah lutut, yaitu anak diajarkan untuk berusaha keras dalam menggapai apa yang diinginkannya, pantang menyerah, tidak mudah putus asa. Di dalam keluarga juga memiliki aturan sendiri, memberikan kebebasan kepada anaknya sesuai dengan kapasitas yang dimiliki, mendukung keinginan anak dalam hal positif, terbuka, tegas, dan mengajarkan anak-anaknya tidak mudah putus asa dalam menggapai apa yang diinginkannya. Apabila anak mengalami masalah orang tua akan membantu untuk menyelesaikan masalah dengan kepala dingin, bersahabat, dan memberikan kesempatan untuk memperbaiki kesalahannya

\section{Ucapan Terima Kasih}

Penelitian ini tidak akan terlaksana tanpa adanya bantuan dari berbagai pihak. Melalui kesempatan ini penulis menyampaikan terima kasih kepada semua pihak yang telah membantu dalam pelaksanaan penelitian hingga penyusunan artikel ilmiah ini. Secara khusus penulis menyampaikan terima kasih kepada masyarakat suku Dayak Lundayeh di Kota Tarakan yang telah bersedia menjadi sampel penelitian ini. Semoga semua curahan bantuan yang diberikan berbalas pahala oleh Tuhan Yang Maha Kuasa.

\section{Daftar Rujukan}

Agency, B. \& Tridhonanto, A. (2014).Mengembangkan Pola Asuh Demokratis. Jakarta: PT. Gramedia. Depdikbud.(1988). Kamus Besar Bahasa Indonesia. Jakarta: Balai Pustaka.

Dewi, H.I.R. (2014). Pola Asuh Dalam Keluarga Masyarakat Samin (Studi Kasus Desa Klopoduwur). Skripsi (tidak diterbitkan). Semarang: Universitas Negeri Semarang.

Djamarah, S.B. (2014). Pola Asuh Orang Tua dan Komunikasi Dalam Keluarga. Jakarta: Rineka Cipta.

Ekawati, S. (2015). Peningkatan Kecerdasan Emosi Anak Melalui Bermain Tebak Ekspresi Dalam. http://eprints.ums.ac.id/2015/9/11.NASKAH_PUBLIKASI_SAFITRI.pdf.

Fransiska, S. (2019). Pengasuhan Anak Usia Dini Pada Keluarga Dayak di Rumah Betang Ensaid Panjang. Jurnal Golden Age Hamzanwadi University, 3(02). http://www.e-journal. hamzanwadin.ac.id/index.php/jga/article/view/1655/0.

Gunarsa, S. (2002). Psikologi Perkembangan Anak dan Remaja. Jakarta: Gunung Mulya.

Moleong, L.J. (2018). Metodologi Penelitian Kualitatif. Bandung: PT Remaja Rosdakarya.

Pratisti, W.D. (2008). Psikologi Anak Usia Dini. Jakarta: PT Indeks.

Septiari, B.B. (2012). Mencetak Balita Cerdas dan Pola Asuh Orangtua. Yogyakarta: Nuha Medika.

Shochib, M. (2014). Pola Asuh Orang Tua (Dalam Membantu Mengembangkan Disiplin Diri). Jakarta: Rineka Cipta.

Sugiyono. 2011. Metode Penelitian Pendidikan Pendekatan Kuantitatif, Kualitatif dan RED. Bandung: CV. Alfabeta.

Susanto, A. (2015). Bimbingan dan Konseling di Taman Kanak-Kanak. Jakarta: Prenadamedia Group. 
50 Pola asuh suku dayak lundayeh di kota tarakan

Yansen, G. \& Ricky, Y. (2018). Dayak Lundayeh Idi Lun Bawang Budaya Serumpun di Dataran Tinggi Borneo. Palangka Raya: Lembaga Literasi Dayak.

\section{Competing interests:}

The authors declare that they have no significant competing financial, professional or personal interests that might have influenced the performance or presentation of the work described in this manuscript. 